\title{
Biology and Management of Garden Spurge (Euphorbia hirta) in Ornamental Crop Production'
}

\author{
Thomas Smith, Chris Marble, Shawn Steed, and Nathan Boyd ${ }^{2}$
}

\section{Introduction}

Garden spurge (Euphorbia hirta) is a prostrate (lowgrowing), herbaceous, short-lived, warm-season annual weed commonly found in Florida landscapes, container nurseries, and other agricultural production areas. This article is written to aid green industry professionals and others in the identification and management of garden spurge in and around ornamental plants.

\section{Species Description}

\section{Class}

Dicotyledon

\section{Family}

Euphorbiaceae-Spurge family

\section{Other Common Names}

Pillpod sandmat, asthma spurge, asthma weed, hairy spurge

\section{Life Span}

Warm-season annual

\section{Habitat}

Garden spurge (Figure 1) is a common weed in agriculture fields, container-grown ornamentals, landscape planting beds, lawns, gardens, and other disturbed areas. In container nurseries, garden spurge can be found in containers, in pot drain holes, growing through weed mats, and in non-crop areas around the nursery. In landscapes, it is frequently found growing in turfgrass or in mulched planting beds, but it is also commonly found growing in sidewalk cracks and between patio pavers. Garden spurge prefers warm and sunny locations but can also grow in dense shade.

\section{Distribution}

Garden spurge is native to tropical and subtropical regions of North America but has naturalized throughout tropical and subtropical areas throughout the world (USDA-NRCS 2020). In the United States, garden spurge is commonly found in the southeastern states, as far north as North Carolina and west to California (USDA-NRCS 2020). Current distribution outside the US includes South and

1. This document is ENH1322, one of a series of the Environmental Horticulture Department, UF/IFAS Extension. Original publication date July 2020. Visit the EDIS website at https://edis.ifas.ufl.edu for the currently supported version of this publication.

2. Thomas Smith, graduate research assistant, Environmental Horticulture Department; Chris Marble, assistant professor, Environmental Horticulture Department, UF/IFAS Mid-Florida Research and Education Center; Shawn Steed, UF/IFAS Extension multi-county environmental horticultural agent III; and Nathan Boyd, associate professor, Horticultural Sciences Department, UF/IFAS Gulf Coast Research and Education Center; UF/IFAS Extension, Gainesville, FL 32611.

The use of trade names in this publication is solely for the purpose of providing specific information. UF/IFAS does not guarantee or warranty the products named, and references to them in this publication do not signify our approval to the exclusion of other products of suitable composition. All chemicals should be used in accordance with directions on the manufacturer's label. Use pesticides safely. Read and follow directions on the manufacturer's label.

The Institute of Food and Agricultural Sciences (IFAS) is an Equal Opportunity Institution authorized to provide research, educational information and other services

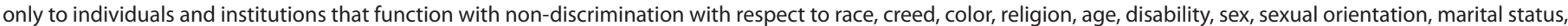

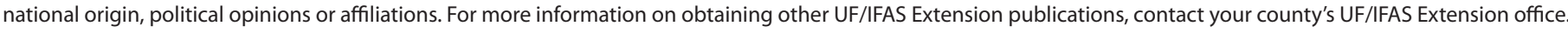
U.S. Department of Agriculture, UF/IFAS Extension Service, University of Florida, IFAS, Florida A \& M University Cooperative Extension Program, and Boards of County Commissioners Cooperating. Nick T. Place, dean for UF/IFAS Extension. 
East Asia, the Pacific Islands, Australia, and pan-tropical America (Queensland Government 2016).

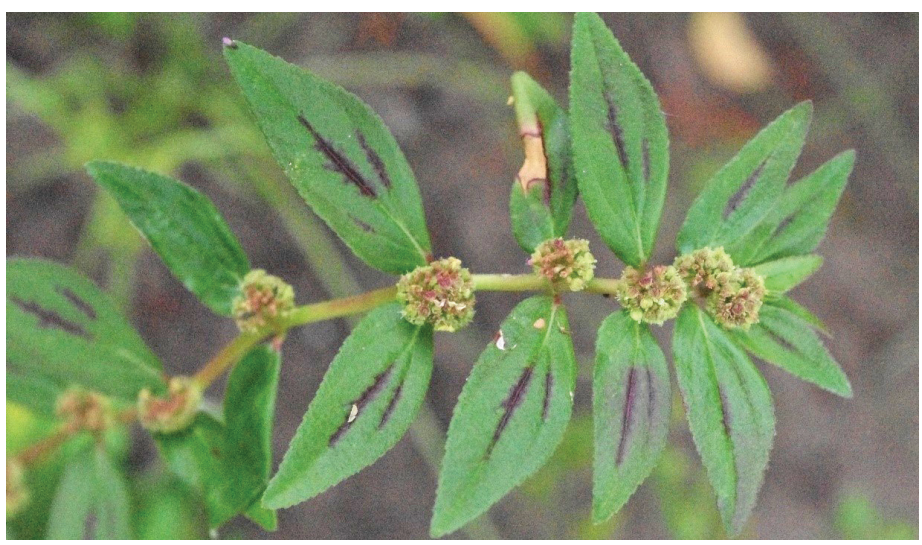

Figure 1. Garden spurge (Euphorbia hirta) growing through a weed mat at a nursery.

Credits: Annette Chandler, UF/IFAS

\section{Growth Habit}

Garden spurge is a low-growing (prostrate) herbaceous annual plant. Stems are prostrate to ascending, and may reach 6 to 20 inches in length. Garden spurge stems arise from a central taproot and are reddish purple and covered with yellowish to dark brown hairs. Vegetative tissue (stems, leaves, etc.) discharges a milky latex sap when broken (Neal and Derr 2005).

\section{Seedling}

Garden spurge seedlings are green to reddish in color with opposite leaves that are obovate (narrow leaves at the base) with small serrations (teeth) around the leaf edges (Figures 2 and 3) (Molinar et al. 2009; Invasive Species Compendium 2019).

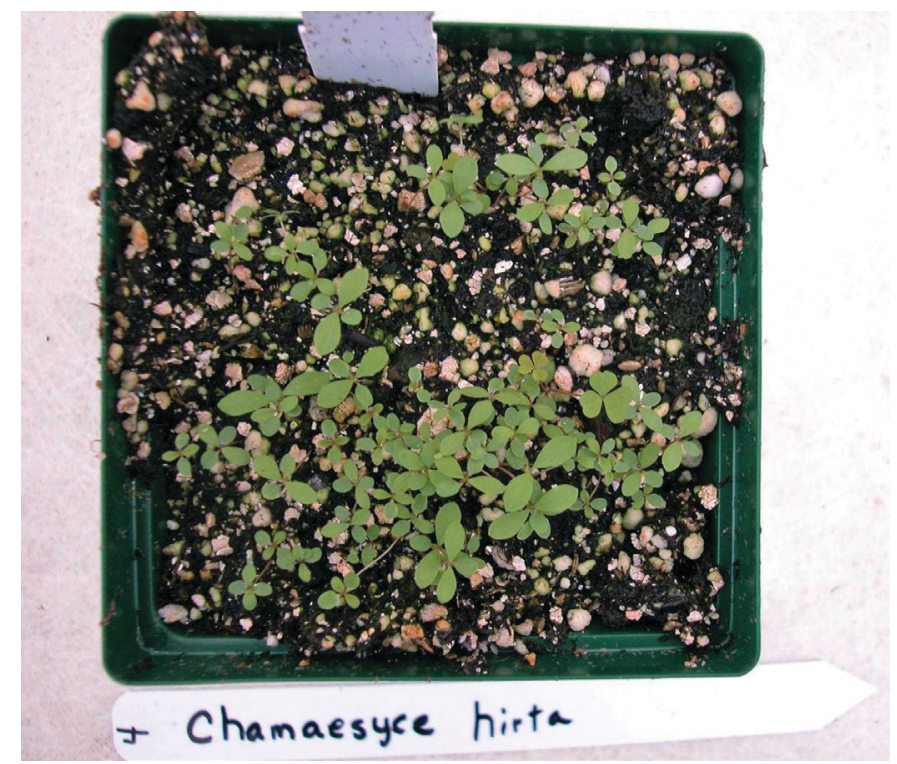

Figure 2. Young garden spurge seedlings several days after germination.

Credits: Annette Chandler, UF/IFAS

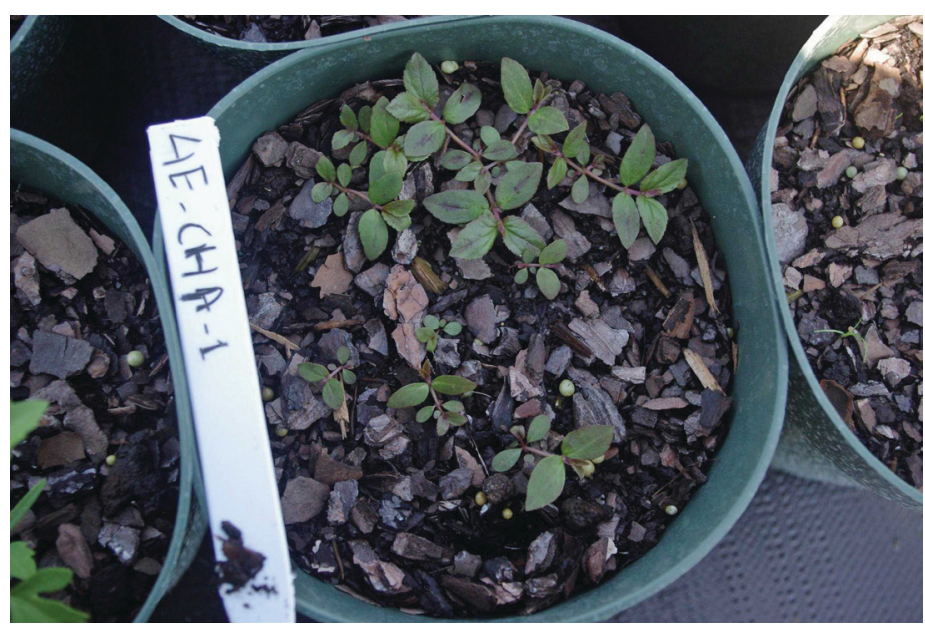

Figure 3. Young garden spurge seedlings, approximately 2 weeks after germination.

Credits: Annette Chandler, UF/IFAS

\section{Shoot}

Stems emerge from a central taproot. They are reddish to purple in color and coated with dense yellow hairs. When found in heavy shade, leaves may be more greenish in color. Stems and leaves contain a milky latex sap. Leaves are opposite and oblong to lanceolate in shape with a pointed tip. Finely serrated (toothed) margins are typically 0.5 to 1.5 inches long (Invasive Species Compendium 2019). Leaves may have a reddish/purplish spot.

\section{Roots}

Garden spurge has a main taproot that can reach up to 24 inches in length but is usually around 4 to 6 inches long. The rest of its root mass consists of secondary fibrous roots growing off the main taproot. Garden spurge does not usually root at nodes. Spread is mostly through seed production (Invasive Species Compendium 2019).

\section{Inflorescence}

Flowers (cyathia-type flowers) are very small and emerge from the leaf axils in a round, globular-like cluster on top of the stems. The clusters of flowers are usually 0.2 to 0.4 inches in diameter, and may be tan to greenish to pinkish in color. Flowers are monoecious (both male and female flower structures) and have no petals, consisting only of stamens and pistils with a brown peduncle (stem that connects the flowers to the stem) (Invasive Species Compendium 2019).

\section{Fruit and Seeds}

Fruits are 3-lobed and split into 3 one-seeded segments. One mature plant can produce several thousand seeds over the course of just 8 to 10 weeks. Fruit are tan in color and 
measure approximately 0.05 to 0.08 inches by 0.06 inches. Seeds are oblong and very small with a reddish-brown color (Invasive Species Compendium 2019).

\section{Similar Species}

As a group, the spurges (Euphorbia spp.) are the most common broadleaf weeds in container nurseries in the southeastern United States with over 30 species documented in Florida (Wunderlin et al. 2020). Of all the spurge species, three are generally most common in landscapes and nurseries: garden spurge, spotted spurge (Euphorbia maculata), and hyssop spurge (Euphorbia hyssopifolia). Hyssop spurge can be differentiated from garden spurge because it tends to have rounder leaves and has an upright growing habit (Figure 4). Garden spurge and spotted spurge have the same prostrate growth habit, but spotted spurge leaves are much rounder in shape than those of garden spurge and are usually about half their size (Figure 5).

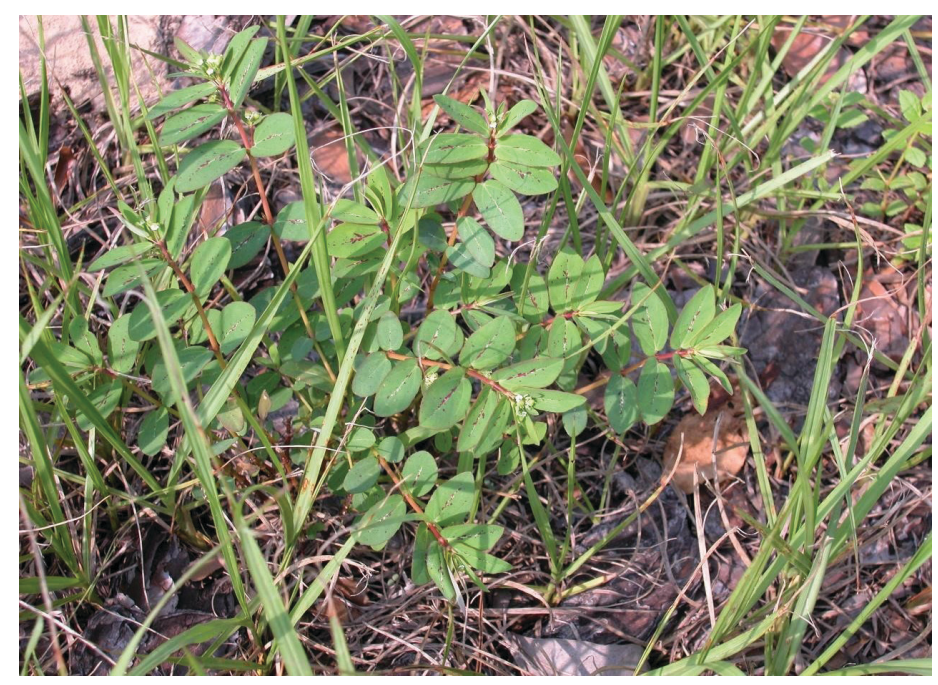

Figure 4. Hyssop spurge growing in a non-crop area. Note the upright growth habit and rounded leaves.

Credits: Annette Chandler, UF/IFAS

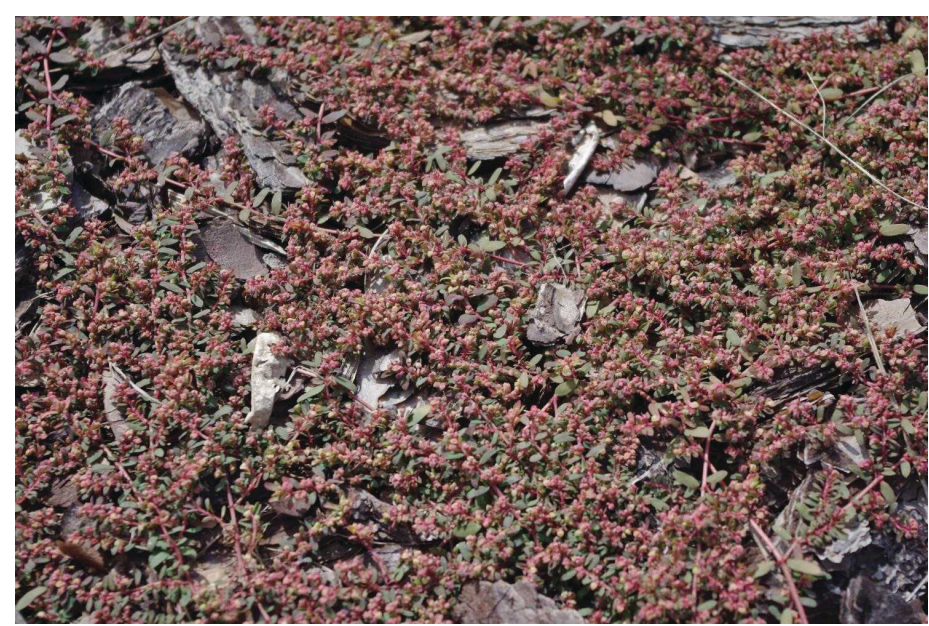

Figure 5. Spotted spurge growing in a thin layer of pine bark mulch. Credits: Annette Chandler, UF/IFAS

\section{Plant Biology}

Garden spurge is one of the most common weeds in Florida landscapes and container nurseries. Seed germination is highest at temperatures between $75^{\circ} \mathrm{F}$ and $85^{\circ} \mathrm{F}$ but can occur any time temperatures are over $60^{\circ} \mathrm{F}$. In central and south Florida, germination occurs throughout most of the year while germination is limited to spring and summer in cooler climates. Plants can begin to produce seeds in as little as 6 to 8 weeks after germination. Garden spurge seeds have no dormancy requirement, meaning that once seeds are mature, they are viable; they begin to germinate and grow once they are dispersed (Neal and Derr 2005). In landscapes and nurseries, seeds are often spread by wind, water, and mowing equipment.

\section{Management Physical and Cultural Control}

In landscapes, mulch such as pine bark or pine straw applied at a depth of 2 to 3 inches can prevent garden spurge emergence because its seeds require light to germinate (Saha et al. 2019). Because garden spurge does not root along its nodes, it can usually be removed effectively by hand-weeding. Hoeing, tilling, and raking control emerged shoots, but these are often not practical in most landscape situations. Mowing is generally not an effective management approach due to garden spurge's low prostrate growth habit (Thralls 2019). In nurseries, mulches such as pine bark nuggets, rice hulls, or other mulch materials that dry quickly after irrigation offer control. Hand-weeding is also effective, but it is important to hand-weed frequently (every 2 to 4 weeks) because of garden spurge's fast growth rate and its ability to quickly produce seeds following germination.

\section{Chemical Control}

Most postemergence herbicides that have activity on broadleaf weeds offer control of garden spurge. Systemic herbicides such as glyphosate (RoundUp ${ }^{\circledR}$ and many other trade names) can be used on large established plants, and would be recommended in cases where the area was heavily infested with spurge and other weed species. Because garden spurge is an annual weed, contact herbicides such as diquat (Reward ${ }^{\circledR}$ ) and glufosinate (Finale ${ }^{\circledR}$ ) are highly effective if coverage is thorough. For a complete list of postemergence herbicide options labeled for use in nurseries and landscapes, see EDIS document ENH95, Postemergent Herbicides for Use in Ornamentals. In container-grown ornamentals, garden spurge is managed most successfully with preemergence herbicides because no over-the-top 
broadleaf postemergence herbicides are available for use. Even in cases where postemergence herbicides can be used, such as in landscape beds, preemergence herbicides are often recommended to prevent reinfestation due to garden spurge's fast growth rate and high seed production. Effective active ingredients include dimethenamid-P, indaziflam, flumioxazin, and herbicide combinations that include one of these active ingredients. Table 1 shows a list of preemergence herbicides labeled for use in landscapes and production ornamentals, including example trade names, application rates, and efficacy rankings for garden spurge.

\section{References}

Invasive Species Compendium. 2019. "Data Sheet

Euphorbia hirta (Garden Spurge)." CABI. Ac-

cessed January 9, 2020. https://www.cabi.org/isc/

datasheet/21355\#F56A69A1-CDEF-4FC0-B00C-

A17039BDBEE5

Jabeen, N., and A. Moinuddin. 2009. "Possible Allelopathic Effect of Three Different Weeds on Germination and Growth of Maize (Zea mays) Cultivars." Pak. J. Bot. 41:

1677-1683.

Molinar, R. H., D. W. Cudney, C. L. Elmore, and A. Sanders. 2009. "Pest Notes: Spurge and Other Spurges." UC ANR Publ. No. 7445. Accessed January 20, 2020. http://ipm. ucanr.edu/PMG/PESTNOTES/pn7445.html

Neal, J. C., and J. F. Derr. 2005. Weeds of Container Nurseries in the United States. Raleigh, NC: North Carolina Assoc. of Nurserymen, Inc.

Queensland Government. 2016. "Fact Sheet Index." Weeds of Australia Biosecurity Queensland Edition. Accessed January 9, 2020. https://keyserver.lucidcentral.org/weeds/ data/media/Html/chamaesyce_hirta.htm

Saha, D., S. C. Marble, B. J. Pearson, H. E. Perez, G. E. MacDonald, and D. C. Odero. 2019. "Weed Seed Emergence and Growth in Response to Different Physical Properties of Common Landscape Mulch Materials." Weed Technology. Accessed January 20, 2020. https://doi.org/10.1017/ wet. 2019.88

Thralls, E. 2019. “Weed Wars.” UF/IFAS Blogs. Accessed January 10, 2020. https://blogs.ifas.ufl.edu/ orangeco/2019/04/19/weed-wars/
USDA, NRCS. 2020. “The PLANTS Database.” Accessed January 20, 2020. http://plants.usda.gov

Wunderlin, R. P., B. F. Hansen, A. R. Franck, and F. B. Essig. 2020. "Atlas of Florida Plants." Accessed January 20, 2020. http://florida.plantatlas.usf.edu 
Table 1. This table lists registered pesticides that should be integrated with other pest management methods. Additional information on integrated pest management methods can be requested from UF/IFAS Extension horticulture or agriculture agents. A list of local UF/IFAS Extension county offices is available at https://ifas.ufl.edu/. Contact: Weed specialist (Chris Marble, UF/IFAS Mid-Florida Research and Education Center, marblesc@ufl.edu).

\begin{tabular}{|c|c|c|c|c|c|c|c|c|}
\hline $\begin{array}{l}\text { Active } \\
\text { ingredient }\end{array}$ & $\begin{array}{l}\text { Example } \\
\text { trade name/ } \\
\text { formulation }\end{array}$ & $\begin{array}{l}\text { Rate per acre } \\
\text { (Ib ai/acre) }{ }^{1}\end{array}$ & $\begin{array}{l}\text { WSSA } \\
\text { Herbicide } \\
\text { Group }^{2}\end{array}$ & Efficacy $^{3}$ & $\begin{array}{l}\text { Container } \\
\text { production }\end{array}$ & $\begin{array}{c}\text { Field } \\
\text { production }\end{array}$ & $\begin{array}{l}\text { Greenhouses/ } \\
\text { fully enclosed } \\
\text { structures }\end{array}$ & Landscape \\
\hline dithiopyr & Dimension $^{\oplus} 2 \mathrm{EW}$ & $2 \mathrm{pt}(0.5)$ & 3 & $\mathrm{~S}$ & YES & YES & NO & YES \\
\hline \multirow[t]{2}{*}{ pendimethalin } & Pendulum $^{\circledast} 2 \mathrm{G}$ & $200 \mathrm{lb}(4)$ & \multirow[t]{2}{*}{3} & \multirow[t]{2}{*}{$\mathrm{S}$} & YES & YES & NO & YES \\
\hline & Pendulum $^{\circledast} 3.3 \mathrm{EC}$ & $4.8 \mathrm{pt}(2)$ & & & YES & YES & NO & YES \\
\hline prodiamine & Barricade $^{\circledast} 4 \mathrm{FL}$ & $48 \mathrm{fl} \mathrm{oz} \mathrm{(1.5)}$ & 3 & $\mathrm{~S}-\mathrm{C}$ & YES & YES & NO & YES \\
\hline \multirow[t]{2}{*}{ flumioxazin } & Broadstar $^{\mathrm{TM}} 0.25 \mathrm{G}$ & 150 lb (0.375) & \multirow[t]{2}{*}{14} & \multirow[t]{2}{*}{$\mathrm{C}$} & YES & YES & NO & YES \\
\hline & SureGuard $^{\circledR} 4 \mathrm{SC}$ & $12 \mathrm{fl} \mathrm{oz}(0.375)$ & & & YES $^{4}$ & YES $^{4}$ & YES $^{5}$ & YES $^{6}$ \\
\hline oxadiazon & Ronstar $^{\circledast} 2 \mathrm{G}$ & $200 \mathrm{lb}(4)$ & 14 & $\mathrm{~S}$ & YES & YES & NO & YES \\
\hline dimethenamid-P & Tower $^{\circledast} 6 \mathrm{EC}$ & $32 \mathrm{fl} \mathrm{oz} \mathrm{(1.5)}$ & 15 & C & YES & YES & NO & YES \\
\hline S-metolachlor & $\begin{array}{l}\text { Pennant Magnum }{ }^{\circledast} \\
7.6 \mathrm{EC}\end{array}$ & $2.6 \mathrm{pt}(2.5)$ & 15 & $\mathrm{~S}$ & YES & YES & NO & YES \\
\hline isoxaben & Gallery ${ }^{\oplus} 4.16 \mathrm{SC}$ & $31 \mathrm{fl} \mathrm{oz} \mathrm{(1)}$ & 21 & $\mathrm{~S}-\mathrm{C}$ & YES & YES & NO & YES \\
\hline \multirow[t]{4}{*}{ indaziflam } & $\begin{array}{l}\text { Specticle }{ }^{\circledast} 0.622 \\
\text { FLO }\end{array}$ & 9 fl oz (0.04) & \multirow[t]{4}{*}{29} & \multirow[t]{4}{*}{$C$} & NO & NO & NO & YES \\
\hline & Specticle ${ }^{\circledR} 0.0224 G$ & $200 \mathrm{lb}(0.04)$ & & & NO & NO & NO & YES \\
\hline & Marengo $^{\circledast} 0.622 \mathrm{SC}$ & 9 fl oz (0.04) & & & $\mathrm{NO}^{7}$ & YES & YES $^{8}$ & NO \\
\hline & Marengo ${ }^{\oplus} 0.0224 \mathrm{G}$ & 200 lb (0.04) & & & YES & YES & NO & NO \\
\hline $\begin{array}{l}\text { pendimethalin + } \\
\text { dimethenamid-P }\end{array}$ & FreeHand $^{\circledast} 1.75 \mathrm{G}$ & $200 \mathrm{lb}(2+1.5)$ & $3+15$ & $\mathrm{C}$ & YES & YES & NO & YES \\
\hline $\begin{array}{l}\text { trifluralin + } \\
\text { isoxaben }\end{array}$ & Snapshot $^{\oplus} 2.5 \mathrm{TG}$ & $200 \mathrm{lb}(4+1)$ & $3+21$ & $\mathrm{~S}-\mathrm{C}$ & YES & YES & NO & YES \\
\hline $\begin{array}{l}\text { prodiamine }+ \\
\text { isoxaben }\end{array}$ & Gemini $^{\mathrm{TM}} 3.7 \mathrm{SC}$ & $87 \mathrm{fl} \mathrm{oz}(1.5+1)$ & $3+21$ & $\mathrm{~S}-\mathrm{C}$ & YES & YES & NO & NO \\
\hline $\begin{array}{l}\text { isoxaben + } \\
\text { dithiopyr }\end{array}$ & Fortress $^{\circledR} 0.75 \mathrm{G}$ & $\begin{array}{c}150 \mathrm{lb} \\
(0.75+0.375)\end{array}$ & $3+21$ & $\mathrm{~S}-\mathrm{C}$ & YES & YES & NO & NO \\
\hline $\begin{array}{l}\text { oxyfluorfen + } \\
\text { pendimethalin }\end{array}$ & $\mathrm{OH} 2^{\circledR} 3 \mathrm{G}$ & $100 \mathrm{lb}(2+1)$ & $14+3$ & $\mathrm{~S}-\mathrm{C}$ & YES & YES & NO & YES \\
\hline $\begin{array}{l}\text { flumioxazin + } \\
\text { prodiamine }\end{array}$ & Fuerte $^{\circledR}$ & $\begin{array}{c}100 \mathrm{lb}(0.125+ \\
0.75)\end{array}$ & $14+3$ & C & YES & YES & NO & YES \\
\hline $\begin{array}{l}\text { oxyfluorfen + } \\
\text { prodiamine }\end{array}$ & Biathlon $^{\circledR} 2.75 \mathrm{G}$ & $100 \mathrm{lb}(2+0.75)$ & $14+3$ & $\mathrm{~S}-\mathrm{C}$ & YES & YES & NO & YES \\
\hline \multicolumn{9}{|c|}{$\begin{array}{l}{ }^{1} \text { Rates of herbicide product are listed. Active ingredient applied at that rate is shown parenthetically. Rates shown are generally the highest } \\
\text { recommended label rate for a single application. Check product labels for further details. } \\
{ }^{2} \text { Herbicide groups are based according to primary sites of action and can be used to select herbicides that have differing sites of action (Weed } \\
\text { Technology 17: } 605-619 \text { [2003]) to minimize the potential for the development of herbicide-resistant weeds. } \\
{ }^{3} \mathrm{P}=\text { poor control; } \mathrm{S}=\text { suppression, } \mathrm{C}=\text { good control based on product labels or experimental data evaluating the highest recommended label } \\
\text { rate. } \\
{ }^{4} \mathrm{Can} \text { only be used in selected conifer and deciduous tree species. Check manufacturer's label for a complete list of species and recommended } \\
\text { application methods. } \\
{ }^{5} \mathrm{Can} \text { be applied if no ornamentals are present. Plants can be placed back inside the greenhouse } 24 \mathrm{hr} \text { after application and after product has } \\
\text { been watered in. } \\
{ }^{6} \text { Can be applied as a directed application around established woody landscape ornamentals. }\end{array}$} \\
\hline \multicolumn{9}{|c|}{$\begin{array}{l}{ }^{7} \text { Marengo } 0.622 \mathrm{SC} \text { can be used in pot-in-pot container ornamentals as a directed application only. Specticle }{ }^{\circledR} \text { is the same active ingredient but } \\
\text { labeled for use in landscapes. } \\
{ }^{8} \text { Labeled for use on greenhouse floors, under benches, and other non-crop areas (not to be used on or in the ornamentals). }\end{array}$} \\
\hline
\end{tabular}

